\title{
Analysis and Zonation of Land Vulnerability Areas in Pekon Karangrejo Ulubelu Tanggamus Using Microzonation Method
}

\author{
Eko Rananda*, Lintang Prabowo, Arief Putih Prabowo, Syamsurijal Rasimeng \\ Ida Bagus Suananda Yogi \\ Departement Of Geophysical Engineering, Faculty Of Engineering, University Of Lampung, \\ Jalan Prof. Dr. Sumantri Brojonegoro No. 1 Bandar Lampung 35145, Lampung, Indonesia \\ *Email: ekorananda997@gmail.com
}

Submit: 2020-06-09; Revised: 2020-08-01; Accepted: 2020-08-14

\begin{abstract}
Ulubelu Tanggamus is an area that have geothermal energy potential. This region consists of a geological structure in the form of graben and reverse fault formed between Mount Rendingan and Mount Kukusan. Identifications that can be done include surveys to map soil characteristics in shaking responses using microzonation methods. This study aims to analyze the values of dominant frequency, dominant period, Vs30 and amplification. The stages of the research carried out are processing data to obtain dominant frequency, calculating the value of the dominant period, calculating the value of Vs30 and the amplification value, and making a map of the soil vulnerability of the UlubeluTanggamus area. Based on the distribution of the dominant frequency values, the UlubeluTanggamus geothermal area is dominated by a dominant Frequency $\left(F_{0}\right)>0.5 \mathrm{~Hz}$ which is expected to be a very thick surface thickness of sediments more than $30 \mathrm{~m}$. The distribution of the dominant period value obtained is $\left(T_{0}\right)>1$ where the character of the sedimentary rock type is very soft consisting of alluvial material formed from sedimentation of deltas, top soil, and mud. The distribution of the Vs30 value is dominated by the value of $100<V s 30<200$ and obtains an amplification value of $2<A_{0}<6$ times where the area is an area with a moderate risk category to the danger of soil vulnerability. Keywords: microzonation, dominant frequency, dominant period, Vs30 and amplification
\end{abstract}

\section{INTRODUCTION}

Indonesia is an area that is prone to disasters including earthquakes and landslides, the cause of the disaster is partly due to tectonic processes and soil conditions in an area. The area which is considered to landslides and earthquakes are the Ulubelu Tanggamus geothermal area. This is because there are localized faults formed due to access to the Semangka's regional tectonic movement. Based on these problems, an analysis is needed to determine the dominant frequency and also the vulnerability of the soil. Dominant frequencies and soil vulnerability can be obtained using microzonation methods. Dominant Frequency is a frequency value that often appears so that it is recognized as the frequency value of the rock layers in the region so that the frequency value can indicate the type and characteristics of the rock (Lachet and Brad, 1994).

Microzonation method is one technique to divide a large zone into small zones with the criteria for each zone will differ depending on the purpose of the zoning itself. Soil susceptibility microzonation refers to the value obtained from measurements using a microseismic tool (micro earth vibration detector), so that soil vulnerability is seen from the soil's ability to withstand earthquake vibrations.

Microtremor is an environmental vibration (ambient vibration) which comes from two main sources, namely from humans and nature, microtremor occurs due to vibrations due to people who are walking, vibrations of the engine vibrating factory machines or natural vibrations from the ground (Kanai, 1983). Microtremor recording does not require the existence of sources in the form of earthquakes, but the measurement is done directly because what is recorded is a wave that arises from nature. The location response in the sediment area is closely related to sediment thickness and shear wave velocity, the location response obtained from the spectra comparison technique can be used to determine the thickness of the sediment (Syahruddin et all., 2014). This study shows how to get the value of an area's soil vulnerability based on micro vibrations that occur in the area itself, then the data is mapped into a map to see the safety zone and the zone that is not safe from earthquakes.

The Ulubelu geothermal area is administratively included in the Tanggamus Regency, Lampung Province. Ulubelu is one of the sectors in the northeast of the Semangka fault and part of the Tanggamus region (Suharno, 2003). The location of this research is located in the Mount Duduk complex (Figure 1).

The regional geology of the study area is dominated by young volcanics (Holocene Peistocene) such as breccia, lava and tuffa. In the formation of Hulusimpang (Olocosene miocene) consists of volcanic breccias and lava. Old rocks are found in the Mount Kasih complex with metamorphic sequences from low to moderate in the northeastern region of young volcanism.

The surface geology in the study area is dominated by quarterly volcanic products and tertiary volcanic, or so 

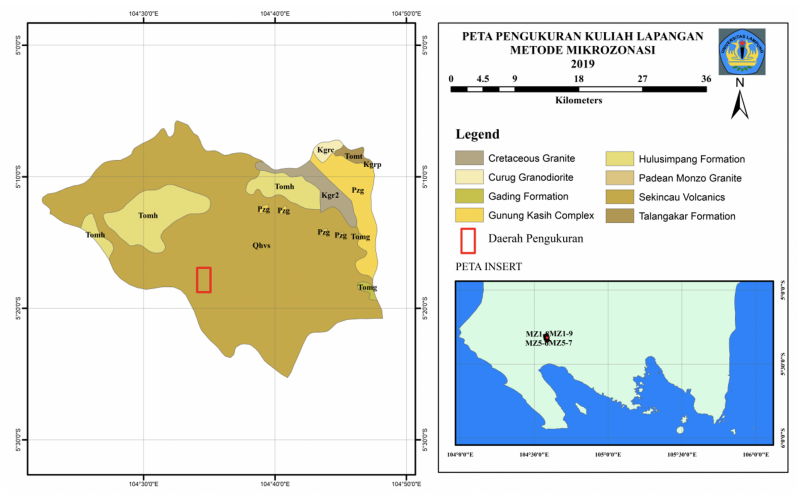

Gambar 1. Map of the Microzonation Research Area

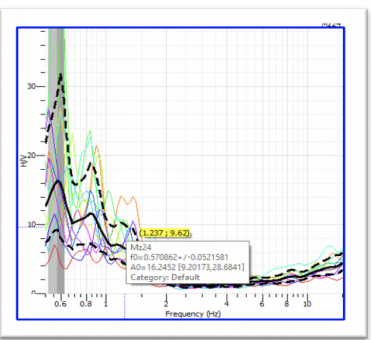

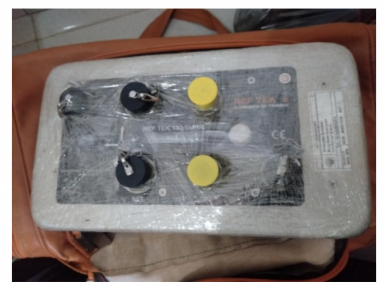

(b)
Gambar 2. a) dominant frequency data, b) Reftex 130-SMHR (a device used to detect microtremor waves)

called Tanggamus volcanics. Alluvium and alteration rocks are in the southwest part of the study area. Many layers are heated but the altration layer of the geothermal system is in the middle of the study area close to the Pagaralam area on the Ulubelu caldera. With the direction of the trend from north to south and south-west, parallel to the Belu river and Ngarip river. Mount Sulah, Mount Kukusan and Mount Duduk are composed of andesitic, basaltic and volcanic dacits during the Pliocene period. The mountains are in the middle of the study area with volcanic products heading west and southwest (Suharno, 2003).

\section{DATA AND METHOD}

There are 26 Microzonation survey point data in Pekon Karang Rejo Ulubelu Geothermal Area, Tanggamus Regency. Microzonation data processing is carried out in several stages, namely using the CMD program to convert data with PAS2SAC. This data conversion is done so that the waves recorded by the microtremor measurement tool (Figure $2 \mathrm{~b}$ ) can be read on the Geopsy software to be processed at a later stage. In this geopsy software, we will get the dominant frequency value (Figure 2a).

After getting the dominant frequency then proceed with calculating the value of the dominant period, the value of Vs30 and the amplification value. Dominant period value is the time required for microtremor waves to propagate through the surface sediment deposition layer or come through one reflection of the surface reflectance plane, the

\begin{tabular}{|c|c|c|c|c|}
\hline \multicolumn{2}{|c|}{ Land Classification } & \multirow[b]{2}{*}{$\begin{array}{c}\text { Period } \\
\text { (T) (second) }\end{array}$} & \multirow[b]{2}{*}{ Explanation } & \multirow[b]{2}{*}{ Characteristic } \\
\hline Kanai & $\begin{array}{c}\text { Omote - } \\
\text { Nakajima }\end{array}$ & & & \\
\hline Type I & & $0.05-0.15$ & Tertiary or older rocks. & Hard \\
\hline Type II & Type A & $0.10-0.25$ & $\begin{array}{l}\text { Alluvial rocks, with a } \\
\text { thickness of } 5 \mathrm{~m} . \\
\text { Consists ofsandy- } \\
\text { gravel,sandy hard clay, } \\
\text { loam, etc. }\end{array}$ & medium \\
\hline Type III & Type B & $0.25-0.40$ & $\begin{array}{l}\text { Alluvial rocks, with } \\
\text { thickness }>5 \mathrm{~m} \text {. } \\
\text { Consists ofsandy- } \\
\text { gravel hard clay, loam, } \\
\text { etc. }\end{array}$ & Soft \\
\hline Type IV & Type C & $>0.40$ & $\begin{array}{l}\text { Alluvial material, } \\
\text { which is formed from } \\
\text { sedimentation of deltas, } \\
\text { topsoils, mud, etc. }\end{array}$ & Very Soft \\
\hline
\end{tabular}

\begin{tabular}{lll}
\multicolumn{3}{l}{ Table 2. Classification of Rock Types Based on Uniform Building Code (UBC). } \\
\hline Rock type & Rock type profile & Vs $_{\mathbf{3} 0}$ \\
\hline A & Hard rock & $>1500 \mathrm{~m} / \mathrm{s}$ \\
B & Mid Rock & $760-1500 \mathrm{~m} / \mathrm{s}$ \\
C & Very dense soil and soft rock & $360-760 \mathrm{~m} / \mathrm{s}$ \\
D & Stiff soil & $180-360 \mathrm{~m} / \mathrm{s}$ \\
E & Soft soil & $<180 \mathrm{~m} / \mathrm{s}$ \\
\hline
\end{tabular}

dominant period value also indicates the character of rock layers in Table 1 in an area.

The dominant period value is obtained based on the equation

$$
T_{0}=\frac{1}{f_{0}}
$$

Where: $T_{0}=$ Dominant period (s) $f_{0}=$ Dominant frequency (hz)

Vs30 is the speed of the shear wave to a depth of $30 \mathrm{~m}$ from the surface. The value Vs30 can be used in determining earthquake resistant building standards. The value Vs30 is used to determine the rock classification based on the strength of vibrations generated from the earthquake due to local effects and is used in the design of earthquake resistant buildings. Characteristics or properties of rocks are needed to analyze the dynamic nature of rocks, so that the rock stiffness and shear strength of the soil can be determined by measuring the shear wave velocity to a depth of $30 \mathrm{~m}$. rock type classification based on the average propagation velocity of shear waves to a depth of $30 \mathrm{~m}$ (Vs30) can be seen in Table 2 .

The VS30 value is obtained using the equation,

$$
V S_{30}=4 h f_{0}
$$

Where, $V s_{30}=$ shear wave velocity to a depth of $30 \mathrm{~m}$ from the surface $(\mathrm{m} / \mathrm{s}) h=$ layer depth $(\mathrm{m}) f_{0}=$ dominant frequency $(\mathrm{Hz})$

Amplification is directly proportional to the value of the horizontal and vertical spectral ratio $(\mathrm{H} / \mathrm{V})$. The amplification value can increase, if the rock has been deformed (weathering, folding or enlarged) which changes the physical properties of the rock. In the same rock, the amplification value can vary according to the level of deformation 


\begin{tabular}{llll}
\multicolumn{4}{l}{ Table 3. Division of soil amplification zones (Marjiyono, 2010). } \\
\hline No & Amplification of soil & Color in Mapping & Risk description \\
& & & \\
\hline 1 & $0-3$ & Blue & Low \\
2 & $3-6$ & Green & Medium \\
3 & $6-9$ & Yellow & High \\
4 & More than 9 & Red & Very high \\
\hline
\end{tabular}

and weathering in the rock body (Marjiyono, 2010). Based on this understanding, the amplification can be written in Equation 3 as a function of the comparison of the contrast impedance values, namely:

$$
A_{0}=\left\{\frac{\rho_{0} v_{0}}{\rho_{1} v_{1}}\right\}
$$

Where, $\rho_{0}=$ bedrock density $(\mathrm{gr} / \mathrm{ml}), \rho_{1}=$ mass density of soft rock $(\mathrm{gr} / \mathrm{ml}), v_{0}=$ wave velocity in bedrock $(\mathrm{m} / \mathrm{sec})$, $v_{1}=$ wave velocity in soft rock $(\mathrm{m} / \mathrm{sec})$.

The amount of amplification in making hazard zoning map for Japan (Wakamatsu et al., 2006). Amplification is calculated by the following equation:

$$
\log A m p=2,367-0,82 \log V s 300,166
$$

The geological survey center in this case divides the soil amplification zones shown in Table 3.

\section{RESULT AND DICUSSION}

The observations in this study are the map of the distribution of the dominant frequency values $\left(f_{0}\right)$, the dominant period $\left(T_{0}\right)$, the shear wave velocity to a depth of 30 meters $\left(V s_{30}\right)$, and the amplification value $\left(A_{0}\right)$. The data is then analyzed and processed so that it can be used in the determination of soil vulnerability zones in the Pekon Karang Rejo Ulubelu Geothermal Area, Tanggamus Regency. The rock layers in the Pekon Karang Rejo Ulubelu Geothermal Area are mostly by young volcanics (Holocene-Pleistocene) such as breccia, lava and tuffa. In the formation of Hulusimpang (miocene-oligosene) consists of volcanic breccia and lava.

\subsection{Map Analysis of Dominant Frequency Value} $\left(f_{0}\right)$

Based on the map of the distribution of the dominant frequency values in Figure 3, it can be interpreted that in Pekon Karang Rejo, Ulubelu Geothermal Area has a dominant frequency value ranging from $0.57-1.35 \mathrm{~Hz}$.

The distribution of dominant frequency values $(0.5<$ $f 0<1 H z)$ is in Pekon Karang Rejo Ulubelu Tanggamus Geothermal Area. The area is an area with type IV classification according to Kanai (Table 4) with an indication that the thickness of the surface sediment is very thick.

\subsection{Map Analysis of Dominant Period Values $\left(T_{0}\right)$}

Based on the map of the distribution of dominant period values in Figure 4, it can be interpreted that in Pekon Karang Rejo the Ulubelu Tanggamus Geothermal Area has a dominant period value ranging from 0.73 to 1.78 sec.

The distribution of dominant period values in the Pekon
Table 4. Soil Classification Based on Dominant Frequency Value of Microtremor By Kanai (Arifin et all, 2014).

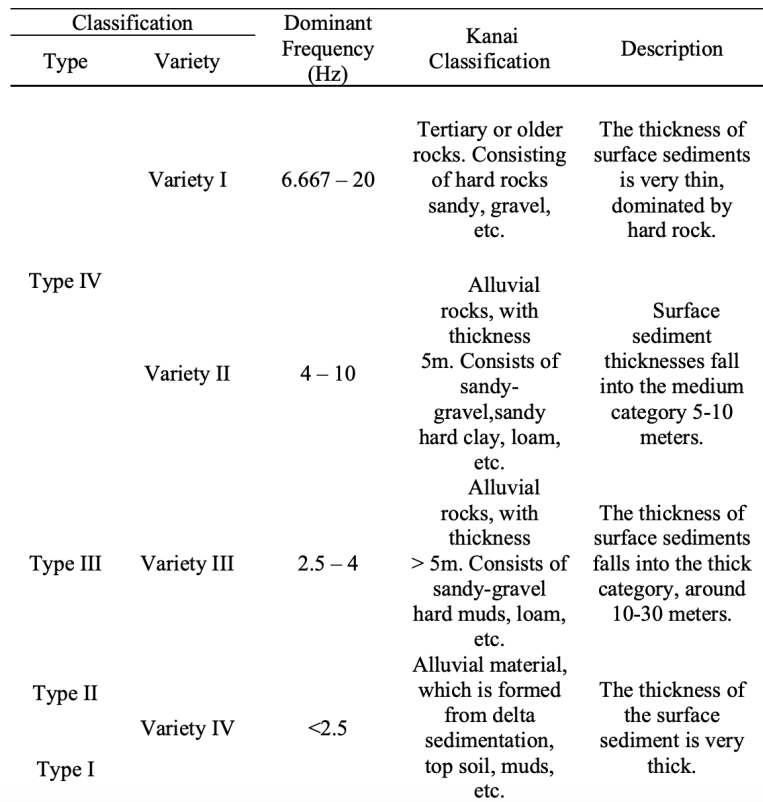

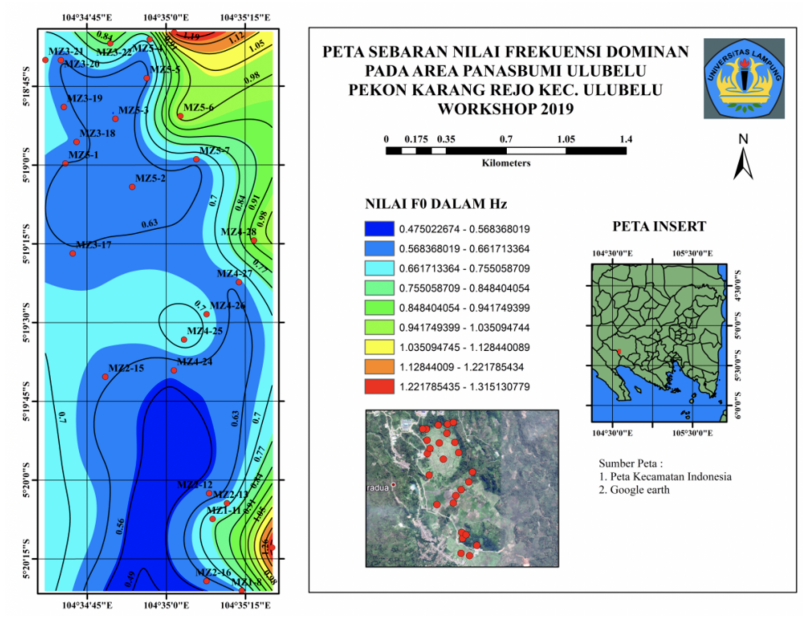

Gambar 3. Map of the distribution of dominant frequency values $\left(f_{0}\right)$ of Pekon Karang Rejo Ulubelu Tanggamus Geothermal Area.

Karang Rejo Ulubelu Tanggamus area is $T 0>0,4$ second. The area is an area of type $\mathrm{C}$ classification according to Omote-Nakajima (Table 1) with an indication of the character of very soft sedimentary rock types in the form of alluvial material, which is formed from sedimentation of deltas, topsoils, muds.

\subsection{Analysis of Vs30 Value Distribution Maps}

On the distribution map the value of Vs30 shown in Figure 5 is connected with the value of the dominant frequency, to create a site class at the value of Vs30 that follows the value of the dominant frequency.

Based on the measurement results, it can be seen that the Pekon Karang Rejo area of the Ulubelu Tanggamus Geothermal Area has a Vs30 value ranging from 67.39 - 156 $\mathrm{m} / \mathrm{s}$ which means the profile of the rock type is included in 


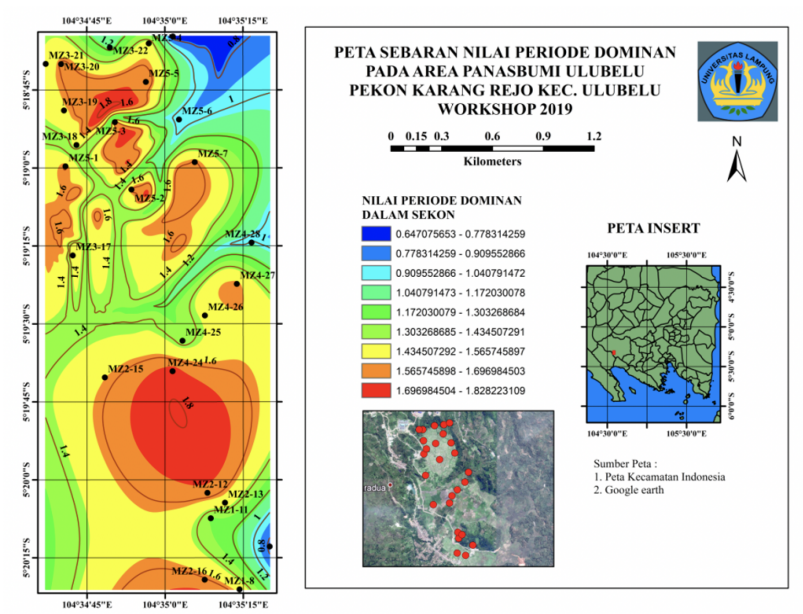

Gambar 4. Map of the distribution of dominant period values $\left(T_{0}\right)$ of Pekon Karang Rejo Ulubelu Tanggamus Geothermal Area
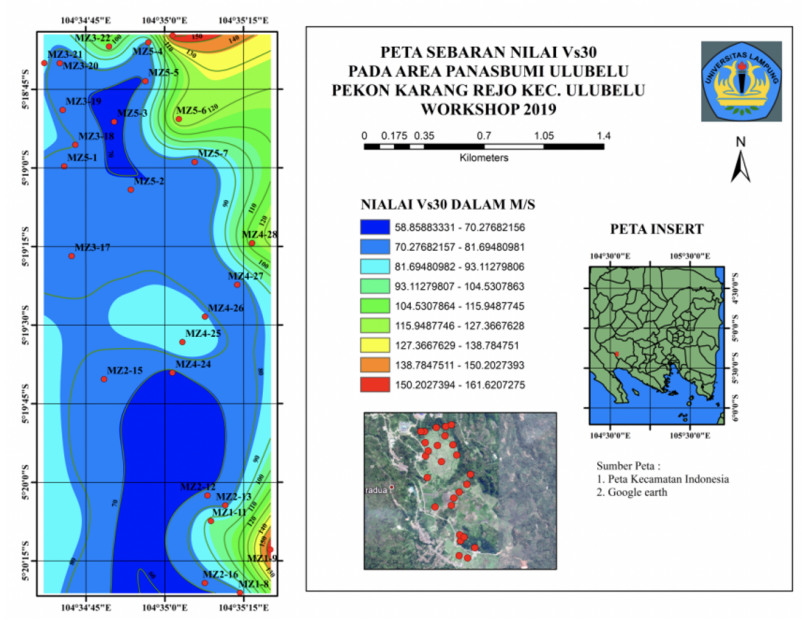

Gambar 5. Map distribution of the Vs30 value of Karang Rejo Village Ulubelu Tanggamus Geothermal Area.

soft soil based on the classification of rock types based on uniform building code ( UBC) (Table 2).

\subsection{Amplification Value Distribution Map Analysis $\left(A_{0}\right)$}

Based on the distribution map the amplification value in Figure 6 can be interpreted that the Pekon Karang Rejo area of the Ulubelu Tanggamus Geothermal Area has an amplification value ranging from 3.04 to 6.44 times.

Based on the analysis of the dominant frequency values above by comparing the amplification values it can be concluded that the dominant frequency values are inversely proportional to the amplification values. The amplification value can increase, if the rock has been deformed (weathering, folding or enlarged) which changes the physical properties of the rock. In the same rock, the amplification value can vary according to the level of deformation and weathering in the rock's body.

After analyzing the map and amplification data, if the Vs30 value is small it will have a high amplification. The

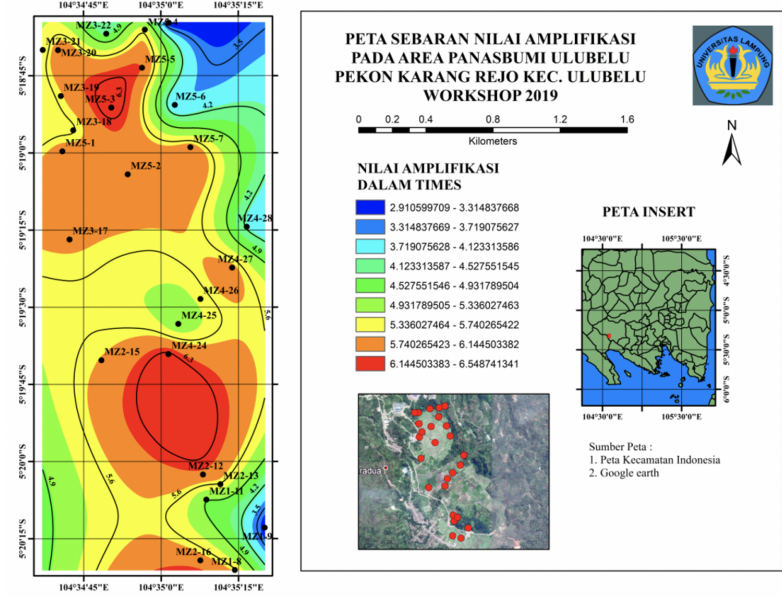

Gambar 6. Map of the distribution of Amplification value (A0) of Pekon Karang Rejo Ulubelu Tanggamus Geothermal Area.

map shows that the Pekon Karang Rejo Ulubelu Tanggamus Geothermal Area is included in this low amplification zone because the Vs30 value ranges from 67.39 - $156 \mathrm{~m} / \mathrm{s}$ resulting in amplification between 3.04 - 6.44 times magnification, which means the area has a risk soil vulnerability with low categories based on the division of land amplification zones (Table 3). This information was concluded based on the calculation of the amplification value of the study area in the Pekon Karang Rejo Ulubelu Tanggamus Geothermal Area.

\section{CONCLUSIONS}

The dominant frequency value of Karang Rejo Village $(f 0<$ $2.5 \mathrm{~Hz}$ ) ranges from $0.57-1.35 \mathrm{~Hz}$ so that it is classified as type IV with an indication of the thickness of surface sediment included in the category is very thick more than $30 \mathrm{~m}$. The dominant period value of Karang Rejo Village $\left(T_{0}>0.4 s\right)$ ranges from $0.73-1.78$ seconds with type C classification which is assumed to be very soft sedimentary rock character in the form of alluvial material, which is formed from delta, topsoil, mud sedimentation. The value of Vs30 pekon Karang Rejo $(0<V s 30<300 \mathrm{~m} / \mathrm{s})$ ranges from 67.39 - $156 \mathrm{~m} / \mathrm{s}$ is the same as the distribution of dominant frequency values $\left(f_{0}<2.5 \mathrm{~Hz}\right)$ with the profile of rock types included in soft soil (soil soft). The amplification value of Pekon Karang Rejo ranges from 3.04 to 6.44 times, so it can be said that the UlubelubeluTanggamus Area is an area with a moderate risk category.

\section{ACKNOWLEDGMENTS}

The author would like to thank Mr. Syamsurijal Rasimeng as the lecturer in charge of the 2019 workshop who has allowed this research data for our publication.

\section{REFERENCES}

Arifin, S. S., Mulyatno, B. S., Marjiyono, Setyanegara, R., 2014. Penentuan Zona Rawan Guncangan Bencana Gempa Bumi Berdasarkan Analisis Nilai Amplifikasi HVSR Mikrotremor 
18 Rananda et al. (2020)

dan Analisis Periode Dominan Daerah Liwa dan Sekitarnya. Jurnal Geofisika Eksplorasi Vol 2/No.1.

Kanai, K., 1983. Engineering Seismology. University of Tokyo Press Japan.

Lachet, C., Brad, P. Y., 1994. Numerical and Theoretical Investigation on The Possibilities and Limitations of Nakamura's Technique. Jurnal Physics Earth 42 377-397.

Marjiyono, 2010. Estimasi Karakteristik Dinamika Tanah Dari Data Mikrotremor Wilayah Bandung. Thesis ITB. Bandung.

Suharno, 2003. Geophysical, Geological and Paleohydrological Studies of the Rendingan-Ulubelu-Waypanas (RUW) Geothermal System Lampung Indonesia. The University of Auckland, Auckland.

Syahruddin, M. H., Aswad, S., Palullungan, E. F., Maria, Syamsuddin, 2014. Penentuan Profil Ketebalan Sedimen Lintasan Kota Makassar dengan Mikrotremor Universitas Hasanuddin. Jurnal Fisika Vol. 4 No. 1, Mei 2014.

Wakamatsu, K., Matsuoka, M., Hasegawa, K., 2006. GIS-based Nationwide Hazard Zoning Using the Japan Engineering Geomorphologic Classification Map. Proceedings of the 8th U.S. National Conference on Earthquake Engineering San Francisco California USA pp. 849. 